\title{
APPLICATION OF SCENARIO ANALYSIS IN THE INVESTMENT PROJECTS EVALUATION
}

\author{
Tomislav Brzaković ${ }^{1}$, Aleksandar Brzaković2 ${ }^{2}$ Jelena Petrovic ${ }^{3}$
}

\begin{abstract}
Sumarry
Investing represents an investment in the present to achieve certain effects in the future, and risk is an essential part of the investment process. Scenario analysis involves key risk factors of the project, its sensitivity to changes in key factors and the likelihood of their changes. Scenario analysis allows us to assign probabilities to the base case, the best case and the worst case so that we can find the expected value and standard deviation of the project's NPV to get a better idea of the project's risk. The goal is to determine whether it is possible to make relevant investment decisions on the basis of the parameters of projects risk, such as the standard deviation and the coefficient of variation. The paper is based on a mathematical model, applied to a specific agricultural company. In our case, the project has a wide range of possibilities and a large potential negative value, which suggests a great risk of the project. Although the scenario analysis shows a higher risk, it is not clear if the project should be accepted or not, and therefore, it is necessary to conduct simulation analysis, in order to get reliable answers.
\end{abstract}

Keywords: evaluation, investment project, agriculture, risk, return

JEL: $Q 19, G 31$

\section{Introduction}

Riskiness of the investment project is defined as the variability of cash flows of the project in relation to expected trends (Tapiero, 2004). In the context of investment appraisal, risk refers to the business risk of an investment, which increases with the variability of expected returns

1 Tomislav Brzaković Ph.D, Full Professor, University Business Academy, Faculty of Applied Management, Economics and Finance, Nemanjina street no. 4, Belgrade, Serbia, Phone: +38163218220, E-mail: tomislavbrzakovicmef@gmail.com

2 Aleksandar Brzaković M.A., University Business Academy, Faculty of Applied Management, Economics and Finance, Nemanjina street no. 4, Belgrade, Serbia, Phone: +3816312666 62, E-mail: aleksandar.brzakovic@gmail.com

3 Jelena Petrović M.A., University Business Academy, Faculty of Applied Management, Economics and Finance, Nemanjina street no. 4, Belgrade, Serbia, Phone: +381 6386826 30, E-mail: jobradovic777@gmail.com

EP 2016 (63) 2 (501-513) 
(Watson, Head, 2007). A project with a higher variability is riskier (Van Horne, Waskovicz, 2007). Because investors require a higher rate of return when companies undertake risky projects, these companies will have a higher cost of capital (Gervais, 2009). There are three major components of risk of each project: individual project risk (stand-alone risk), the risk of the project for the company and market risk. Stand-alone risk is the risk of an individual project which ignores the effects of diversification and, observed in isolation, is of low importance (Brigham, Ehrhardt, 2014). Individual risk assessment of a project can be obtained by analyzing the expected internal rate of return and its standard deviation, as a result of the volatility of expected cash flows. Unlike stand-alone risk, project risk for the company is seen as a contribution to the overall project risk exposure of the company (Orsag, 2002). The company is practically a portfolio of assets. Proceeds from these various assets are not always moving in the same direction, i.e., are not perfectly correlated positively with each other (Gitman, 2009). Therefore, the individual risk of a project is important if it changes the company portfolio risk. In other words, risky project for the company depends on the correlation of its internal rate of return and profitability of existing companies. The lower the correlation between them, the smaller the impact of the project on the riskiness of the company is. Market risk refers to the risk of a relevant project in relation to shares of companies that will keep investors' portfolios well diversified (Shim, Siegel, 2009). Market risk depends on the correlation of project profitability and the capital markets profitability. The lower the correlation between the profitabilities, the lower the market risk is. The project will reduce the individual risk of the project in the market portfolio.

\section{Literature review}

Decisions on capital investments require analysis of future cash flows of the desired project, uncertainty of future cash flows and the value of future cash flows (Dedi, Orsag, 2007). Since nothing in the future is certain, investors are faced with the risk associated with future cash flows (Brealey, Myers, Allen, 2014). Typically, for the assessment of project cash flow, the following several methods are used: sensitive analysis, scenario analysis and simulation process. Sensitive analysis does not examine the probability distribution of the net present value of the project. For this reason, the results and conclusions of the sensitive analysis should be supplemented by the results of other methods of testing individual risk projects. In contrast to the sensitivity analysis, scenario analysis involves both key risk factors of the project: its sensitivity to changes in key factors and the likelihood of their changes (Brigham, Ehrhardt, 2011). Scenario analysis is a behavioral approach that uses several possible alternative outcomes (scenarios), to obtain a sense of the variability of returns, measured here by NPV. This technique is often useful in getting a feel for the variability of return in response to changes in a key outcome (Gitman, Zutter, 2012) When the factors are of an interdependent size, scenario analysis provides insight into various combinations of factors that show how the project would look in different scenarios. It encourages „,contingent thinking“, describing the future by a collection of possible eventualities (Pike, Neale, 2006). Estimating income or expenses under certain scenarios provides more accurate estimates than an absolute assessment of optimistic or pessimistic values. The 
scenario analysis is based on the formation of discrete probability distributions achieving a net present value of the project and its analysis using normal distribution (Parrino, Kidwell, Bates, 2012). Basic techniques of risk assessment based on normal distribution where the observed volatility or variability of possible outcomes around the expected value of the distribution probability. The basic measures of risk are: standard deviation (standard deviation), the variance and coefficient of variation (Fabozzi, Drake, 2009). For the risks to be viewed in a particular portfolio, the risk analysis must include knowledge of the correlation between different sizes and measure the correlation - covariance and correlation coefficient. It is also necessary to recognize and $\beta$ (beta) ratio, a measure of elasticity of the yield changes yield investments towards companies or the efficiency of the overall capital markets (Fabozzi, Drake, 2010). If, for example, coefficient of variation of the project extends beyond a company, the project is riskier than the average project manager, and vice versa (Brealey, Myers, Allen, 2014). In contrast to the sensitivity analysis where we changed one variable at a time, in scenario analysis we can modify several of the inputs to be better or worse than expected. We can choose as many scenarios as we like, however, by selecting any number of different sets of outcomes for the cash flows. Evaluating a number of scenarios gives a subjective feel for the variability of the NPV to changes in our assumptions about what the cash flows will turn out to be (Lasher, 2008). The portrayal of optimistic and pessimistic scenarios may be useful in providing managers with some feel for the 'downside' risk and 'upside' potential associated with a project (Atrill, 2009). Also, scenario analysis allows us to assign probabilities to the base case, the best case, and the worst case. After that we can find the expected value and standard deviation of the project's NPV to get a better idea of the project's risk (Bodie, Kane, Marcus, 2009).

\section{Problem and work methodology}

The paper is based on a mathematical model. As an example we used Agropro d.o.o., a company which plans to produce innovative technology for the production of organic vegetables. This represents an important expansion project for the company. The company has a license for the production for a period of 4 years and which it received from the inventor. The company opted to use a straight-line depreciation method.

Probability distribution can be expressed using two parameters of distribution: (1) the expected value and (2) the standard deviation.

The expected value of the cash flow is a weighted average of the possible cash flows, where the weights are the probabilities of occurrence. The expected value of the probability distribution of cash flows for the period $t$, is defined as:

$$
\overline{C F_{t}}=\sum_{x=1}^{n}\left(C F_{x t}\right)\left(P_{x t}\right)
$$

where:

CFxt $=$ cash flow for the possibility of $x$ in period $t$,

$\mathrm{Pxt}=$ probability of occurrence of cash flow, 
$\mathrm{n}=$ total number of possible occurrence of cash flow in period $\mathrm{t}$.

Standard deviation is a common measure of dispersion. The standard deviation of the cash flow in period $t$, can be expressed mathematically as:

$$
\sigma_{t}=\sqrt{\sum_{x=1}^{n}\left(C F_{x t}-\overline{C F_{t}}\right)^{2}\left(P_{x t}\right)}
$$

Square of the standard deviation, $\sigma^{2}$, is known as the variance of the distribution.

A measure of the relative dispersion of the probability distribution of the coefficient of variation $(\mathrm{CV})$ is mathematically defined as the ratio of the standard deviation of the distribution and the expected value of the distribution:

$$
C V=\frac{S D}{\overline{C F_{t}}}
$$

In a scenario analysis, we begin with the base-case scenario, which uses the most likely value for each input variable. We then specify the worst-case scenario (low unit sales, low sales price, high variable costs, and so on) and the best-case scenario (Brigham, Ehrhardt, 2014). Due to the high variability of those factors in the agricultural company, it is recommendation the use scenario analysis in evaluating projects. Often the best and the worst cases are defined as having a $25 \%$ probability of occurring, with a $50 \%$ probability for the base-case conditions. Table 1 . shows the probability and inputs assumed for the base-case, the worst-case and the best case scenarios.

Table 1. Inputs for Each Scenario (Dollars in Thousands)

\begin{tabular}{|l|c|c|c|}
\hline & \multicolumn{3}{|c|}{ Scenarios: } \\
\hline Scenario Name & Base & Worst & Best \\
\hline Probability of Scenario & $50 \%$ & $25 \%$ & $25 \%$ \\
\hline Inputs: & & & \\
\hline Equipment cost & $\$ 8,000.00$ & $\$ 8,250.00$ & $\$ 7,250.00$ \\
\hline Salvage value of equip. in Year 4 & $\$ 1,600.00$ & $\$ 1,400.00$ & $\$ 1,900.00$ \\
\hline Units sold, Year 1 & $10,000.00$ & $8,500.00$ & $11,500.00$ \\
\hline$\% \Delta$ in units sold, after Year 1 & $10 \%$ & $5.00 \%$ & $20.00 \%$ \\
\hline Sales price per unit, Year 1 & $\$ 1.50$ & $\$ 1.25$ & $\$ 1.75$ \\
\hline$\% \Delta$ in sales price, after Year 1 & $5 \%$ & $3.00 \%$ & $6.00 \%$ \\
\hline Var. cost per unit (VC), Year 1 & $\$ 1.07$ & $\$ 1.17$ & $\$ 0.97$ \\
\hline$\% \Delta$ in VC, after Year 1 & $4 \%$ & $6.00 \%$ & $3.00 \%$ \\
\hline Nonvar. cost (Non-VC), Year 1 & $\$ 2,000.00$ & $\$ 2,200.00$ & $\$ 1,800.00$ \\
\hline$\% \Delta$ in Non-VC, after Year 1 & $4 \%$ & $6.00 \%$ & $3.00 \%$ \\
\hline Project cost of capital (r) & $10 \%$ & $15.00 \%$ & $5.00 \%$ \\
\hline Tax rate & $20 \%$ & $30.00 \%$ & $15.00 \%$ \\
\hline NOWC as \% of next year's sales & $20 \%$ & $25.00 \%$ & $15.00 \%$ \\
\hline
\end{tabular}

Source: Author's calculations 


\section{Paper goals}

The paper observed factors that have the largest impact on net present value, and examine their effect on the NPV of the project in different scenarios. The success of this proposed investment project depends on many factors, including the equipment cost, unit sales, sales price per unit, variable cost per unit, nonvariable cost, project cost of capital and others (Moyer, McGuigan, Rao, Kretlow, 2012).

The goal is to determine whether it is possible to make relevant investment decisions on the basis of the parameters of projects risk, such as the standard deviation and the coefficient of variation. The significance of this paper is to show whether on the basis of scenario analysis the relevant investment decision can be made.

This paper consists of introduction, literature review, problem and work methodology, results and discussions, conclusion and references. Results and discussions

Table 2., 3., and 4., illustrate how these assumptions and the resulting project NPV might vary under alternative scenarios.

Table 2. Analysis for Base Scenario

\begin{tabular}{|c|c|c|c|c|c|}
\hline Intermediate Calculations & 0 & 1 & 2 & 3 & 4 \\
\hline Unit sales & & $10,000.00$ & $11,000.00$ & $12,100.00$ & $13,310.00$ \\
\hline Sales price per unit & & $\$ 1.50$ & $\$ 1.58$ & $\$ 1.65$ & $\$ 1.74$ \\
\hline $\begin{array}{l}\text { Variable cost per unit } \\
\text { (excl. depr.) }\end{array}$ & & $\$ 1.07$ & $\$ 1.11$ & $\$ 1.16$ & $\$ 1.20$ \\
\hline $\begin{array}{l}\text { Nonvariable costs (excl. } \\
\text { depr.) }\end{array}$ & & $2,000.00$ & $2,080.00$ & $2,163.20$ & $2,249.73$ \\
\hline $\begin{array}{l}\text { Sales revenues }=\text { Units } \times \\
\text { Price/unit }\end{array}$ & & $15,000.00$ & $17,325.00$ & $20,010.38$ & $23,111.98$ \\
\hline $\begin{array}{l}\text { NOWC }_{t}= \\
20 \%\left(\text { Revenues }_{t+1}\right)\end{array}$ & $3,000.00$ & $3,465.00$ & $4,002.08$ & $4,622.40$ & 0.00 \\
\hline Basis for depreciation & $8,000.00$ & & & & \\
\hline Annual depreciation rate & & $25.00 \%$ & $25.00 \%$ & $25.00 \%$ & $25.00 \%$ \\
\hline $\begin{array}{l}\text { Annual depreciation } \\
\text { expense }\end{array}$ & & $\$ 2,000.00$ & $\$ 2,000.00$ & $\$ 2,000.00$ & $\$ 2,000.00$ \\
\hline $\begin{array}{l}\text { Remaining undepreciated } \\
\text { value }\end{array}$ & & $\$ 6,000.00$ & $\$ 4,000.00$ & $\$ 2,000.00$ & $\$ 0.00$ \\
\hline \multirow[t]{2}{*}{ Cash Flow Forecast } & & \multicolumn{4}{|c|}{ Cash Flows at End of Year } \\
\hline & 0 & 1 & 2 & 3 & 4 \\
\hline $\begin{array}{l}\text { Sales revenues }=\text { Units } \times \\
\text { Price/unit }\end{array}$ & & $\$ 15,000.00$ & $\$ 17,325.00$ & $\$ 20,010.38$ & $\$ 23,111.98$ \\
\hline $\begin{array}{l}\text { Variable costs }=\text { Units } \times \\
\text { Cost/unit }\end{array}$ & & $\$ 10,700.00$ & $\$ 12,240.80$ & $\$ 14,003.48$ & $\$ 16,019.98$ \\
\hline $\begin{array}{l}\text { Nonvariable costs } \\
\text { (excluding depreciation) }\end{array}$ & & $\$ 2,000.00$ & $\$ 2,080.00$ & $\$ 2,163.20$ & $\$ 2,249.73$ \\
\hline Depreciation & & $\$ 2,000.00$ & $\$ 2,000.00$ & $\$ 2,000.00$ & $\$ 2,000.00$ \\
\hline $\begin{array}{l}\text { Earnings before interest } \\
\text { and taxes (EBIT) }\end{array}$ & & 300.00 & $1,004.20$ & $1,843.70$ & $2,842.28$ \\
\hline
\end{tabular}




\begin{tabular}{|l|l|l|l|l|l|}
\hline Intermediate Calculations & & 0 & 1 & & 2 \\
\hline \\
$\begin{array}{l}\text { Taxes on operating profit } \\
\text { (40\% rate) }\end{array}$
\end{tabular}

Source: Author's calculations

Table 3. Analysis for The Worst Scenario

\begin{tabular}{|c|c|c|c|c|c|}
\hline $\begin{array}{l}\text { Intermediate } \\
\text { Calculations }\end{array}$ & 0 & 1 & 2 & 3 & 4 \\
\hline Unit sales & & $8,500.00$ & $8,925.00$ & $9,371.25$ & $9,839.81$ \\
\hline Sales price per unit & & $\$ 1.25$ & $\$ 1.29$ & $\$ 1.33$ & $\$ 1.37$ \\
\hline $\begin{array}{l}\text { Variable cost per unit } \\
\text { (excl. depr.) }\end{array}$ & & $\$ 1.17$ & $\$ 1.24$ & $\$ 1.31$ & $\$ 1.39$ \\
\hline $\begin{array}{l}\text { Nonvariable costs (excl. } \\
\text { depr.) }\end{array}$ & & $\$ 2,200.00$ & $\$ 2,332.00$ & $\$ 2,471.92$ & $\$ 2,620.24$ \\
\hline $\begin{array}{l}\text { Sales revenues }=\text { Units } \\
\times \text { Price/unit }\end{array}$ & & $\$ 10,625.00$ & $\$ 11,490.94$ & $\$ 12,427.45$ & $\$ 13,440.29$ \\
\hline $\begin{array}{l}\text { NOWC }_{t}= \\
25 \%\left(\text { Revenues }_{t+1}\right)\end{array}$ & $\$ 2,656.25$ & $\$ 2,872.73$ & $\$ 3,106.86$ & $\$ 3,360.07$ & $\$ 0$ \\
\hline Basis for depreciation & $\$ 8,250$ & & & & \\
\hline Annual depreciation rate & & $25 \%$ & $25 \%$ & $25 \%$ & $25 \%$ \\
\hline $\begin{array}{l}\text { Annual depreciation } \\
\text { expense }\end{array}$ & & $\$ 2,062.50$ & $\$ 2,062.50$ & $\$ 2,062.50$ & $\$ 2,062.50$ \\
\hline
\end{tabular}




\begin{tabular}{|c|c|c|c|c|c|}
\hline $\begin{array}{l}\text { Intermediate } \\
\text { Calculations }\end{array}$ & 0 & 1 & 2 & 3 & 4 \\
\hline $\begin{array}{l}\text { Remaining } \\
\text { undepreciated value }\end{array}$ & & $\$ 6,187.50$ & $\$ 4,125.00$ & $\$ 2,062.50$ & $\$ 0.00$ \\
\hline Cash Flow Forecast & & \multicolumn{4}{|c|}{ Cash Flows at End of Year } \\
\hline & 0 & 1 & 2 & $\begin{array}{r}3 \\
\end{array}$ & 4 \\
\hline $\begin{array}{l}\text { Sales revenues }=\text { Units } \\
\times \text { Price/unit }\end{array}$ & & $10,625.00$ & $11,490.94$ & $12,427.45$ & $13,440.29$ \\
\hline $\begin{array}{l}\text { Variable costs }=\text { Units } \times \\
\text { Cost/unit }\end{array}$ & & $9,945.00$ & $11,068.79$ & $12,319.56$ & $13,711.67$ \\
\hline $\begin{array}{l}\text { Nonvariable costs } \\
\text { (excluding depreciation) }\end{array}$ & & $2,200.00$ & $2,332.00$ & $2,471.92$ & $2,620.24$ \\
\hline Depreciation & & $2,062.50$ & $2,062.50$ & $2,062.50$ & $2,062.50$ \\
\hline $\begin{array}{l}\text { Earnings before interest } \\
\text { and taxes (EBIT) }\end{array}$ & & $-3,582.50$ & $-3,972.35$ & $-4,426.53$ & $-4,954.12$ \\
\hline $\begin{array}{l}\text { Taxes on operating } \\
\text { profit ( } 40 \% \text { rate) }\end{array}$ & & $-1,074.75$ & $-1,191.70$ & $-1,327.96$ & $-1,486.24$ \\
\hline $\begin{array}{l}\text { Net operating profit } \\
\text { after taxes }\end{array}$ & & $-2,507.75$ & $-2,780.64$ & $-3,098.57$ & $-3,467.88$ \\
\hline Add back depreciation & & $2,062.50$ & $2,062.50$ & $2,062.50$ & $2,062.50$ \\
\hline Equipment purchases & $-8,250.00$ & & & & \\
\hline Salvage value & & & & & $1,400.00$ \\
\hline $\begin{array}{l}\text { Cash flow due to tax on } \\
\text { salvage value ( } 40 \% \text { rate) }\end{array}$ & & & & & -420.00 \\
\hline $\begin{array}{l}\text { Cash flow due to change } \\
\text { in WC }\end{array}$ & $-2,656.25$ & -216.48 & -234.13 & -253.21 & $3,360.07$ \\
\hline $\begin{array}{l}\text { Opportunity cost, after } \\
\text { taxes }\end{array}$ & 0.00 & 0.00 & 0.00 & 0.00 & 0.00 \\
\hline \multicolumn{2}{|l|}{$\begin{array}{l}\text { After-tax cannibalization or } \\
\text { complementary effect }\end{array}$} & & 0.00 & 0.00 & 0.00 \\
\hline $\begin{array}{l}\text { Project net cash flows: } \\
\text { Time Line }\end{array}$ & $-10,906.25$ & -661.73 & -952.27 & $-1,289.28$ & $2,934.69$ \\
\hline \multicolumn{6}{|c|}{ Project Evaluation Measures: } \\
\hline \multicolumn{4}{|r|}{ NPV } & \multicolumn{2}{|r|}{$-\$ 11,371.53$} \\
\hline \multicolumn{4}{|r|}{ IRR } & \multicolumn{2}{|r|}{$-38.00 \%$} \\
\hline \multicolumn{4}{|r|}{ MIRR } & \multicolumn{2}{|r|}{$-31.14 \%$} \\
\hline \multicolumn{4}{|c|}{ Profitability index } & \multicolumn{2}{|r|}{-0.04} \\
\hline \multicolumn{4}{|c|}{\begin{tabular}{r|} 
Payback \\
\end{tabular}} & \multicolumn{2}{|r|}{ \#N/A } \\
\hline \multicolumn{4}{|c|}{ Discounted payback } & \multicolumn{2}{|r|}{ \#N/A } \\
\hline
\end{tabular}

Source: Author's calculations

In a scenario in which economic conditions are the worst, we expect unit sales to be less than 10,000 because overall demand for units will be lower. The price at which the company sells its product is also lower because the company will probably reduce prices in an effort to boost sales. Also, higher equipment cost, higher variable costs per unit, higher 
non-variable cost, project cost of capital, tax rate and higher required net working capital is assumed.

Table 4. Analysis for The Best Scenario

\begin{tabular}{|c|c|c|c|c|c|}
\hline $\begin{array}{l}\text { Intermediate } \\
\text { Calculations }\end{array}$ & 0 & 1 & 2 & 3 & 4 \\
\hline Unit sales & & $11,500.00$ & $13,800.00$ & $16,560.00$ & $19,872.00$ \\
\hline Sales price per unit & & $\$ 1.75$ & $\$ 1.86$ & $\$ 1.97$ & $\$ 2.08$ \\
\hline $\begin{array}{l}\text { Variable cost per unit } \\
\text { (excl. depr.) }\end{array}$ & & $\$ 0.97$ & $\$ 1.00$ & $\$ 1.03$ & $\$ 1.06$ \\
\hline $\begin{array}{l}\text { Nonvariable costs } \\
\text { (excl. depr.) }\end{array}$ & & $\$ 1,800.00$ & $\$ 1,854.00$ & $\$ 1,909.62$ & $\$ 1,966.91$ \\
\hline $\begin{array}{l}\text { Sales revenues }=\text { Units } \\
\times \text { Price/unit }\end{array}$ & & $\$ 20,125.00$ & $\$ 25,599.00$ & $\$ 32,561.93$ & $\$ 41,418.77$ \\
\hline $\begin{array}{l}\text { NOWC }_{t}= \\
15 \%\left(\text { Revenues }_{t+1}\right)\end{array}$ & $\$ 3,018.75$ & $\$ 3,839.85$ & $\$ 4,884.29$ & $\$ 6,212.82$ & $\$ 0.00$ \\
\hline Basis for depreciation & $\$ 7,250.00$ & & & & \\
\hline $\begin{array}{l}\text { Annual depreciation } \\
\text { rate }\end{array}$ & & $25 \%$ & $25 \%$ & $25 \%$ & $25 \%$ \\
\hline $\begin{array}{l}\text { Annual depreciation } \\
\text { expense }\end{array}$ & & $\$ 1,812.50$ & $\$ 1,812.00$ & $\$ 1,812.50$ & $\$ 1,812.50$ \\
\hline $\begin{array}{l}\text { Remaining } \\
\text { undepreciated value }\end{array}$ & & $\$ 5,437.50$ & $\$ 3,625.00$ & $\$ 1,812.50$ & $\$ 0.00$ \\
\hline Cash Flow Forecast & & \multicolumn{4}{|c|}{ Cash Flows at End of Year } \\
\hline & 0 & 1 & 2 & 3 & 4 \\
\hline $\begin{array}{l}\text { Sales revenues }=\text { Units } \\
\times \text { Price/unit }\end{array}$ & & $\$ 20,125.00$ & $\$ 25,599.00$ & $\$ 32,561.93$ & $\$ 41,418.77$ \\
\hline $\begin{array}{l}\text { Variable costs }=\text { Units } \\
\times \text { Cost } / \text { unit }\end{array}$ & & $\$ 11,155.00$ & $\$ 13,787.58$ & $\$ 17,041.45$ & $\$ 21,063.23$ \\
\hline $\begin{array}{l}\text { Nonvariable } \\
\text { costs (excluding } \\
\text { depreciation) }\end{array}$ & & $\$ 1,800.00$ & $\$ 1,854.00$ & $\$ 1,909.62$ & $\$ 1,966.91$ \\
\hline Depreciation & & $\$ 1,812.50$ & $\$ 1,812.50$ & $\$ 1,812.50$ & $\$ 1,812.50$ \\
\hline $\begin{array}{l}\text { Earnings before } \\
\text { interest and taxes } \\
\text { (EBIT) }\end{array}$ & & $\$ 5,357.50$ & $\$ 8,144.92$ & $\$ 11,798.36$ & $\$ 16,576.13$ \\
\hline $\begin{array}{l}\text { Taxes on operating } \\
\text { profit ( } 40 \% \text { rate) }\end{array}$ & & $\$ 803.63$ & $\$ 1,221.74$ & $\$ 1,769.75$ & $\$ 2,486.42$ \\
\hline $\begin{array}{l}\text { Net operating profit } \\
\text { after taxes }\end{array}$ & & $\$ 4,553.88$ & $\$ 6,923.18$ & $\$ 10,028.61$ & $\$ 14,089.71$ \\
\hline Add back depreciation & & $\$ 1,812.50$ & $\$ 1,812.50$ & $\$ 1,812.50$ & $\$ 1,812.50$ \\
\hline Equipment purchases & $-\$ 7,250.00$ & & & & \\
\hline Salvage value & & & & & $\$ 1,900.00$ \\
\hline
\end{tabular}




\begin{tabular}{|c|c|c|c|c|c|}
\hline \multicolumn{2}{|c|}{$\begin{array}{l}\text { Cash flow due to tax on salvage value } \\
(40 \% \text { rate) }\end{array}$} & \multirow[b]{2}{*}{$-\$ 821.11$} & \multirow[b]{2}{*}{$-\$ 1,044.44$} & \multirow[b]{2}{*}{$-\$ 1,328.53$} & \multirow{2}{*}{$\frac{-\$ 285.00}{\$ 6,212.82}$} \\
\hline $\begin{array}{l}\text { Cash flow due to } \\
\text { change in WC }\end{array}$ & $-\$ 3,018.75$ & & & & \\
\hline $\begin{array}{l}\text { Opportunity cost, after } \\
\text { taxes }\end{array}$ & $\$ 0.00$ & $\$ 0.00$ & $\$ 0.00$ & $\$ 0.00$ & $\$ 0.00$ \\
\hline \multicolumn{2}{|c|}{$\begin{array}{l}\text { After-tax cannibalization or } \\
\text { complementary effect }\end{array}$} & $\$ 0.00$ & $\$ 0.00$ & $\$ 0.00$ & $\$ 0.00$ \\
\hline $\begin{array}{l}\text { Project net cash flows: } \\
\text { Time Line }\end{array}$ & $-\$ 10,268.75$ & $\$ 5,545.28$ & $\$ 7,691.24$ & $\$ 10,512.58$ & $\$ 23,730.03$ \\
\hline \multicolumn{6}{|c|}{ Project Evaluation Measures: } \\
\hline & & & & NPV & $\$ 30,592.56$ \\
\hline & & & & IRR & $74.30 \%$ \\
\hline & & & & MIRR & $48.30 \%$ \\
\hline \multicolumn{5}{|c|}{ Profitability index } & 3.98 \\
\hline \multicolumn{5}{|r|}{ Payback } & 1.61 \\
\hline \multicolumn{5}{|c|}{ Discounted payback } & 1.82 \\
\hline
\end{tabular}

Source: Author's calculations

In contrast to the worst economic scenario, stronger economic conditions might result in higher-than-expected unit sales, prices, and lower initial investment (equipment cost), variable cost per unit, non-variable cost, project cost of capital, tax rate and lower required net working capital.

In Table 1. we can see that the project will have a negative NPV $(-\$ 11,371.53)$ if economic conditions are the worst. Furthermore, the decline in NPV $(\$ 12,953.36$, the difference between $\$ 1,581.83$ and $-\$ 11,371.53$ ) is less than the increase in NPV if economic conditions are the best $(\$ 29,011.03$, the difference between $\$ 30,592.86$ and $\$ 1,581.83)$. The range of NPV values under the three scenarios is $\$ 41,964.39$ (the range between $-\$ 11,371.53$ and $\$ 30,592.86$ ). This wide range of possibilities, and especially the large potential negative value, suggests that this is a risky project. If bad conditions materialize, the company will realize a loss on the project of $\$ 11,371,530$. In contrast, if they achieve favorable forecasts, the company will realize a gain on the project of $\$ 30,592,860$.

Although this analysis can help us better understand how much uncertainty is associated with an NPV estimate, there is only one NPV value for a project and the FCF values we use in an NPV analysis represent the expected incremental free cash flows (Ignjatijević, 2015). Scenario analysis extends risk analysis in two ways: (1) it allows us to change more than one variable at a time and, therefore, see the combined effects of changes in several variables on NPV; (2) it allows us to bring in the probabilities of changes in the key variables. Figure 1. presents the cash flows and net present value (NPV) for each scenario. Using the NPV and probability for each scenario, we calculated the expected NPV, the standard deviation, and 
the coefficient of variation.

Figure 1. Scenario Analysis: Expected NPV and Its Risk (Dollars in Thousands)

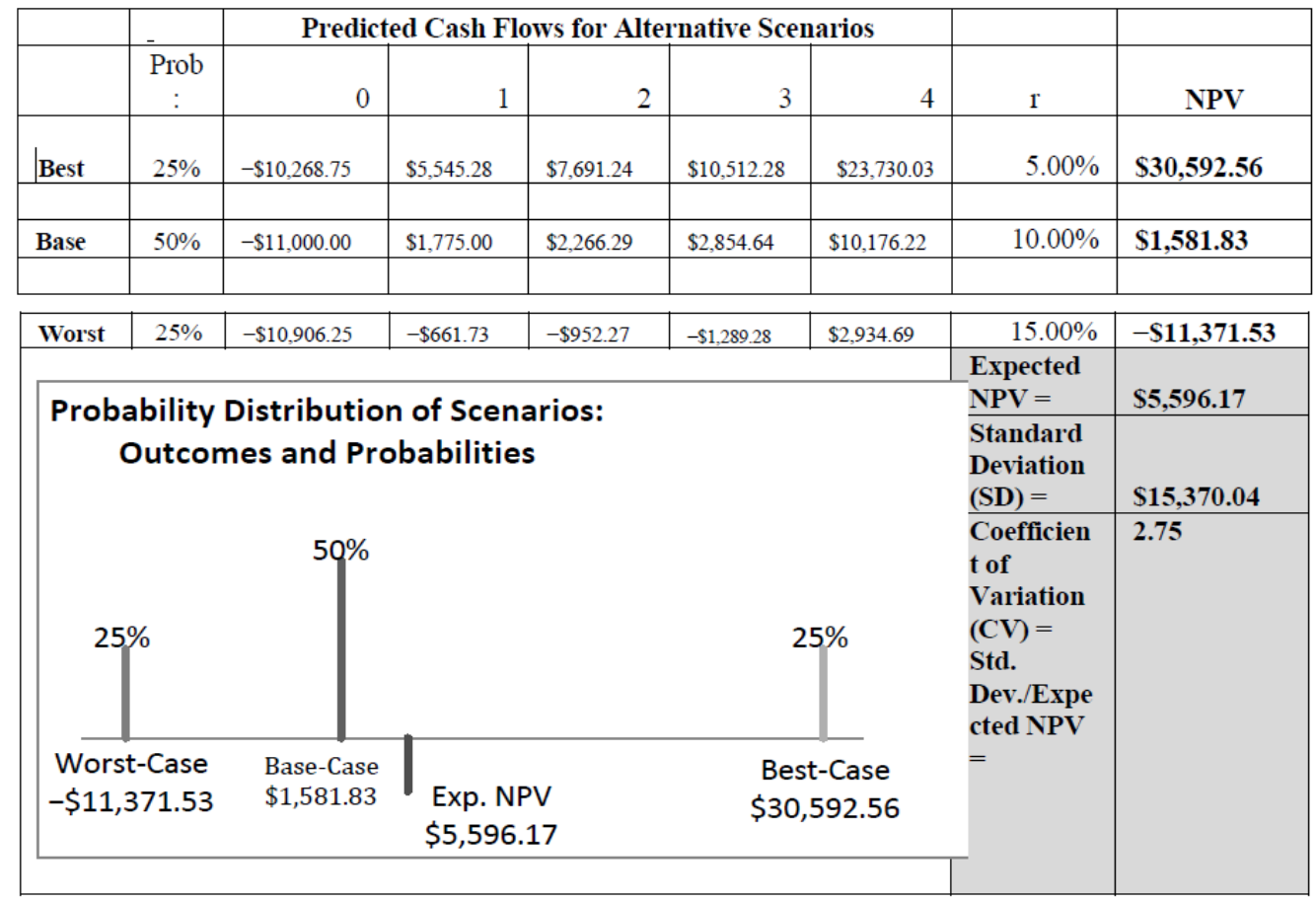

\section{Source: Author's calculations}

The preliminary analysis of the base case indicates that the project is acceptable. The company has a positive net present value (NPV=1,581.83). The internal rate of return $(\mathrm{IRR}=14.84 \%)$ and modified internal rate of return $(\mathrm{MIRR}=13.76 \%)$ are higher than the cost of capital. Profitability index is larger than 1. If the company expected Payback and Discounted Payback period to be less than 4, than the investment is also acceptable in these criteria. But, when we multiply each scenario's probability by the NPV for that scenario and then add the products, as shown in Figure 1., we have the project's expected NPV of $\$ 5,596.17$, which is significantly higher than the NPV base case $(\$ 1,581.83)$. Expected NPV differs from the base-case NPV which is the most likely outcome because it has a 50\% probability. Standard deviation of the expected NPV is $\$ 15,370.04$. Dividing the standard deviation by the expected NPV yields the coefficient of variation, 2.75, which is a measure of stand-alone risk. The coefficient of variation measures the amount of risk per dollar of NPV, so the coefficient of variation can be helpful when comparing the risk of projects with different NPVs or with the risk of the whole company. If the average coefficient of variation of the company projects is 1.25 , this means that the considered project is more than twice as risky. Although the scenario analysis shows higher risk, it is not clear if the project should be accepted or not. Therefore, it is necessary to conduct simulation analysis, in order to get reliable answers. 


\section{Conclusions}

Investing is a complex process. Making investment decisions is one of the most subtle and the most important decisions with long-term implications. Investment represents an investment in the present to achieve certain effects in the future, and risk is an essential part of the investment process. Risk is uncertainty that the expected results of the project will not be realized or will deviate from the plan. In other words, the risk of the investment project is the variability of cash flows of the project in relation to expected cash flows.

Scenario analysis involves key risk factors of the project - its sensitivity to changes in key factors and the likelihood of their changes. When the factors are of an interdependent size, scenario analysis provides insight into the various combinations of factors that shows how the project would look in different scenarios. Because of this reason it is widely used, including project evaluation and risk of agricultural companies. Scenario analysis allows us to assign probabilities to the base case, the best case, the worst case and find the expected value and standard deviation of the project's NPV to get a better idea of project's risk. Scenario analysis extends risk analysis in two ways: it allows us to change more than one variable at a time and hence, see the combined effects of changes in several variables on NPV and it allows us to bring in the probabilities of changes in the key variables.

The preliminary analysis of the base case indicates that the project is acceptable. But, when we multiply each scenario's probability by the NPV for that scenario and then add the products, we have higher the project's expected NPV than the NPV base case. Standard deviation of the project and coefficient of variation, which is twice higher then the average coefficient of variation of the company projects, means that the considered project is more than twice as risky. The project has a wide range of possibilities and a large potential negative value suggests that this is a risky project. Although the scenario analysis shows a higher risk, it is not clear if the project should be accepted or not. Therefore, it is necessary to conduct simulation analysis, in order to get reliable answers.

\section{Literature}

1. Bodie, Z., Kane, A., Marcus, A. J. (2009): Osnovi investicija, 6.ed, Datastatus Serbia.

2. Brealey, R.A., Myers, S.C., Allen, F. (2014): Principles of Corporate Finance, 11 ed., McGraw-Hill, USA.

3. Brigham E., Ehrhardt M. (2014): Financial Management: Theory and Practice, 14 Ed., South-Western, Cengage Learning, Canada.

4. Gitman L. J. (2009), Principles of Managerial Finance, 12th ed., Pearson Prentice Hall, USA.

5. Gervais, S. (2009): Behavioral Finance:Capital Budgeting and Other Investment Decisions, Behavioral Finance, USA.

6. Dedi, L., Orsag, S. (2007): Capital budgeting practices: a survey of Croatian firms, South East European Journal of Economics and Business, vol. 2, no. 1, pp. 59-67. 
7. Ehrhardt M. C., Brigham, E.F. (2011): Corporate Finance: A Focused Approach, Fourth Edition, South-Western Cengage Learning, SAD.

8. Ignjatijević, S. (2015): Ekonomska analiza značaja stranih direktnih investicija, Oditor, no. 11, pp. 4-15.

9. Orsag S. (2002): Budžetiranje kapitala: Procjena Investicijskih projekata, Zagreb, Masmedia, Croatia.

10. Parrino R., Kidwell D.S., Bates T. W. (2012): Fundamentals of corporate finance, second edition, John Wiley \& Sons, Inc, USA.

11. Pike, R., Neale, B. (2006): Corporate finance and investment decisions \& strategies, Fifth Edition, FT Prentice Hall, England.

12. Shim J. K., Siegel, J.G. (2009): Budgeting Basics and Beyond, Third edition, Wiley, John Wiley \& Sons, Inc, USA.

13. Van Horne J. C., Waskovicz, J.JR, (2007): Osnovi finansijskog menadžmenta, DATASTATUS, 12. Izdanje, Serbia.

14. Fabozzi, F. J., Drake P. P. (2009): Finance : capital markets, financial management, and investment management, John Wiley \& Sons, USA.

15. Fabozzi, F. J., Drake P. P. (2010): The basics of finance : an introduction to financial markets, business finance, and portfolio management, John Wiley \& Sons, USA.

16. Moyer C., McGuigan J,. Rao R., Kretlow W., (2012): Contemporary Financial Management, South-Western, Cengage Learning, USA.

17. Gitman L., Zutter C., (2012) Principles of Managerial Finance, Prentice Hall, USA.

18. Tapiero C., (2004): Risk and Financial Management, John Wiley \& Sons Ltd, USA.

19. Watson., Head A., (2007): Corporate Finance - Principles \& Practice, Pearson Education Limited, England.

20. Atrill P., (2009): Financial Management for Decision Makers, Pearson Education Limited, England.

21. Lasher W., (2008): Practical Financial Management, Thomson South-Western, USA 


\title{
PRIMENAANALIZE SCENARIJA U POSTUPKU EVALUACIJE INVESTICIONIH PROJEKATA
}

\author{
Tomislav Brzaković4, Aleksandar Brzaković, Jelena Petrovic ${ }^{6}$
}

\begin{abstract}
Sažetak
Investiranje predstavlja ulaganje u sadašnjosti da bi se ostvarili određeni efekati u budućnosti, pa rizik predstavlja neizostavan deo investicionog procesa. Scenarijska analiza obuhvata ključne faktore rizika projekta, osetljivost na promene u ključnim faktorima $i$ verovatnoće njihovih promena. Scenario analiza omogućava dodeljivanje verovatnoće ostvarenja u osnovnom, najboljem i u najgorem slučaju, posle čega se utvrđuje očekivana vrednost $i$ standardna devijacija NPV projekta da bi se dobio bolji uvid u rizik projekta. Cilj je da se utvrdi da li je moguće napraviti relevantne investicione odluke na osnovu parametara rizika projekata, kao što su standardna devijacija i koeficijent varijacije. Rad se zasniva na matematičkom modelu, primenjenom na poljoprivrednoj kompaniji. Unašem slučaju, projekat ima širok spektar mogućnosti i potencijalno veliku negativnu vrednost, što ukazuje na veliki rizik projekta. Iako scenario analiza pokazuje veći rizik, nije jasno da li projekat treba prihvatiti ili ne, i zbog toga je neophodno izvršiti simulacionu analizu, kako bi dobili pouzdane odgovore.
\end{abstract}

Ključne reči: evaluacija, investicioni projekat, novčani tok, rizik, prinos

4 Profesor, dr Tomislav Brzaković, Univerzitet Privredna Akademija, Fakultet za primenjeni menadžment, ekonomiju i finansije, Nemanjina ulica br. 4, Beograd, Srbija, Telefon: +381 63218 220, E-mail: tomislavbrzakovicmef@gmail.com

5 Master Aleksandar Brzaković, Univerzitet Privredna Akademija, Fakultet za primenjeni menadžment, ekonomiju i finansije, Nemanjina ulica br. 4, Beograd, Srbija, Telefon: +381 6312666 62, E-mail: aleksandar.brzakovic@gmail.com

6 Master Jelena Petrović Univerzitet Privredna Akademija, Fakultet za primenjeni menadžment, ekonomiju i finansije, Nemanjina ulica br. 4, Beograd, Srbija, Telefon: +381 6386826 30, E-mail: jobradovic777@,gmail.com

EP 2016 (63) 2 (501-513) 